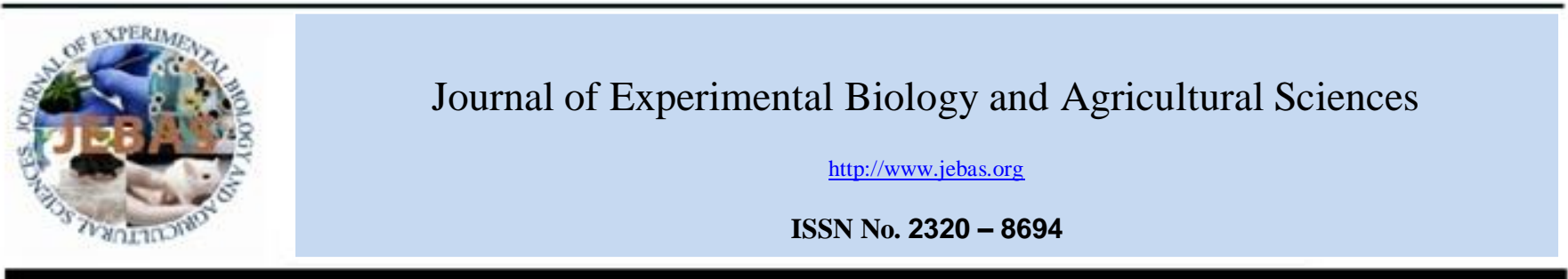

\title{
ANTIMICROBIAL PEPTIDES IN SEMEN EXTENDERS: A VALUABLE REPLACEMENT OPTION FOR ANTIBIOTICS IN CRYOPRESERVATION- A Prospective Review
}

\section{Vickram AS ${ }^{1}$, Kuldeep Dhama ${ }^{2}$, Archana $\mathrm{K}^{3}$, Parameswari $\mathrm{R}^{3}$, Ramesh Pathy $\mathrm{M}^{3}$, Hafiz M. N. Iqbal ${ }^{4}$ and Sridharan T B ${ }^{5 *}$}

\footnotetext{
${ }^{1}$ Department of Biotechnology, School of Biosciences and Technology, Young scientist DST-SERB, Govt. of India, Research Scientist, Vellore Institute of Technology, Vellore, Tamil Nadu, India

${ }^{2}$ Division of Pathology, ICAR-Indian Veterinary Research Institute, Izatnagar, Bareilly, Uttar Pradesh, India

${ }^{3}$ Department of Biotechnology, School of Biosciences and Technology, Vellore Institute of Technology, Vellore, Tamil Nadu, India

${ }^{4}$ Tecnologico de Monterrey, School of Engineering and Sciences, Campus Monterrey, Ave. Eugenio Garza Sada 2501, Monterrey, N.L., CP 64849, Mexico

${ }^{5}$ Department of Biotechnology, Vellore Institute of Technology, Vellore, Tamil Nadu, India
}

Received - September 22, 2017; Revision - October 21, 2017; Accepted - October 25, 2017

Available Online - October 31, 2017

http://dx.doi.org/10.18006/2017.5(5).578.588

\section{KEYWORDS}

Antimicrobial peptides

Semen extenders

Microbial load

Antibiotics

Antibiotic resistant

Semen cryopreservation

\begin{abstract}
Semen extenders or diluents are added to semen before cryopreservation for maintaining its fertilizing ability even after post thaw. Various types of semen extenders are commercially available for porcine, boar, bull, equine and humans. Bacteriospermia in human and animal samples appears to be concentration-time dependent which might affect quality, quantity and longevity of post ejaculated semen in either neat or with extended states. Antibiotics play a significant role in semen extender which ensures long shelf-life to spermatozoa. Also, it protects the female reproductive tract by hindering the transmission of invading pathogens. Although the use of antibiotics in semen extender is monitored by many authorities of respective concerned government, a lot of guidelines and experiments ensuring a proper usage in cryopreservation is in need. The use of antibiotics in semen extenders also pose a threat of antibiotic-resistant bacterial strains in artificial insemination centers (AI) as well as in assisted reproductive technology (ART) laboratories. Development of multi-drug resistant bacteria has been found to be the primary concern when mixture of a wide range of conventional antibiotics is used in semen extenders. Several potent strategies and critical point analysis are of urgent need to hinder the
\end{abstract}

* Corresponding author

Dr. Sridharan T B, Professor, School of Biosciences and Technology,

Vellore Institute of Technology, Vellore

E- Mail: tbsridharan@ vit.ac.in

Peer review under responsibility of Journal of Experimental Biology and Agricultural Sciences.

Production and Hosting by Horizon Publisher India [HPI] (http://www.horizonpublisherindia.in/).

All rights reserved.
All the article published by Journal of Experimental Biology and Agricultural Sciences is licensed under a Creative Commons Attribution-NonCommercial 4.0 International License Based on a work at www.jebas.org.

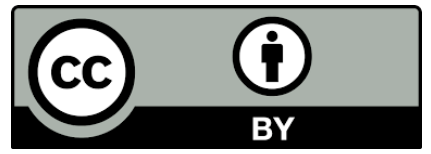


microbial contamination and also to prevent antibiotic-resistant issues. In order to overcome these problems, low evoking resistant antimicrobial peptides (AMPs) have been used by researchers to replace conventional antibiotics. Antimicrobial peptides are positively charged polypeptides with a minimum of 100 amino acids. They possess high structural diversity and proved to be effective against extensive array of pathogens. These AMPs not only act as pathogen defenders but also exhibit immunomodulatory actions. Naturally male and female genital tract contains many antimicrobial peptides that could play not a suitable role against invading pathogens. This review discusses the different types of antimicrobial peptides that could be used in semen extenders during cryopreservation.

\section{Introduction}

Cryopreservation of semen is used routinely in many areas and fields including assisted reproduction, artificial insemination, military persons, in case of pre-radiation and chemotherapy treatments and so on (Schulze et al., 2017). It is treated as fertility insurance for the males undergoing vasectomy and storage of donor semen. Testicular semen samples collected from nonobstructive azoospermia patients were cryopreserved for later usage in in vitro fertilization (IVF) treatment cycles. Cryopreservation allows a single biopsy collected semen samples from testicular sperm aspiration (TESA) and percutaneous epididymal sperm aspiration (PESA) target patients to be used for many intra-cytoplasmic sperm injection (ICSI) cycles. In order to preserve the semen samples in a better way for a long timeand to ensure the feasibility of vital biological functions at subzero temperatures, semen extenders are used. Many types of semen extenders like bovine serum albumin (BSA) based, lecithin based, plant components based, animal protein free and tris based are available commercially in the market for different organisms (Paulenz et al., 2000). Various antibiotics are added to semen extenders to remove the contaminants developed by bacteria and other microbes (Martin et al., 2010). Government agencies and directives are monitoring the antibiotic usage throughout the world.

Given the fact that animal food production related industries rely on cryopreserved semen for artificial insemination (AI), a huge amount of antibiotics are currently used in semen extenders by animal breeders during AI practices. Disadvantage of using a broad range of antibiotics in semen extender is the development of antibiotic resistance over the period of time in the microbe and host organism (Tiwari et al., 2013). In fact the emerging and rising problem of antimicrobial resistant is creating public health concern worldwide (Tiwari et al., 2013; World health organization, 2014; Roca et al., 2015). To overcome this particular problem during cryopreservation, recently researchers have been trying to find an appropriate replacement for antibiotics in semen extender for cryopreservation purposes. Many researchers believed that the valuable replacement option against a broad range of antibiotics in semen extender is the usage of antimicrobial peptides (AMPs) (Da Costa et al., 2013; Schulze et al., 2015).

Host defense peptides (HDPs) are the first line of defense against microbial invasions. These possess direct effect against various bacteria, virus and fungi (Schulze, et al., 2015). Moreover HDPs possess many biological functions like inhibition of lipopolysaccharide (LPS) induced inflammation, immunomodulation (Brown \& Hancock, 2006), and anti-tumor activity, especially these also enhances wound healing. These useful biological properties combined with the raising problem of multiple antibiotic resistance development there is an immediate urgency to shift towards the use of AMPs as better replacement for wide range of conventional antibiotics as semen extenders (Hancock \& Sahl, 2006; Giuliani et al., 2007; Baltzer \& Brown, 2011; Seo et al., 2012). The functions of AMPs have been studied very well by several researchers especially during cryopreservation of boar semen samples for artificial breeding (Bussalleu et al., 2017). Many scientists studied widely about the use of AMPs in semen extenders for replacing conventional antibiotics to minimize the problem of antibiotic resistance development (Martin et al., 2010). Herein, we tried to review various AMPs from different sources and their use in semen extenders as a better replacement for conventional antibiotics for semen cryopreservation purposes.

\section{Semen extenders and their types}

Semen extenders or semen diluents constitute an aqueous solution used to increase the volume of the ejaculated semen and to maintain the functional characteristics of sperm until artificial insemination (AI) (Foote, 2002). Semen extenders have been classified by duration into three different groups like short term, long term and medium term extenders. Short term semen extenders are used in small distance transport and where the semen doses can frequently be made (Paulenz et al., 2000). Longterm semen extenders are used when the semen dose production area and insemination sites are too long. Long time semen 
extenders advantages include: enables transport of semen to longer distances, can facilitate prediction of pregnancy outcome before insemination, and help in distributing the semen doses to different centers. In 1980's time, diluents were based on the glucose solutions without freezing the samples, and later the egg yolk and citrate buffers were used in semen extenders (Paulenz et al., 2000). The important innovation of semen extender research started in early 1960 with the addition of chelating agent like Ethylenediaminetetraacetic acid (EDTA) (Plisko, 1965), which are used to block the action of calcium that helps in capacitation and acrosome reaction during cryopreservation. The major components present in commercial semen extenders are glucose, sodium citrate, sodium bicarbonate, potassium chloride, EDTA, acetylcysteine, Hepes, Tris, citrate, bovine serum albumin (BSA), cysteine, trehalose, polyvinyl alcohol (PVA), 3-(N-morpholino) propanesulfonic acid (MOPS) and glycerol. Semen extenders have also been classified into bovine serum albumin (BSA) based, lecithin based, soya bean based, skim milk based and tris based extenders (Westendorf et al., 1975; Gadea et al., 2003). The liquid diluents/ extenders are used in a way that should possess the following, provide nutrients and help to maintain the sperm cell metabolism, provide valid protection against the cold shock due to cryopreservation, could control the $\mathrm{pH}$ and osmotic pressure and the major concern is to control the development and growth of microorganism during cryopreservation (Gadea et al., 2003). Different types of semen extenders and the kind of antibiotic used by various researchers in the recent years has been tabulated in Table 1. Commercial availability of successful extenders with its antibiotic concentration for use in boar, equine, porcine and human has been tabulated in Table 2 .

\section{Importance of antibiotics in semen extenders}

Mircrobial contamination occurs mainly during the collection process of the semen (Rillo et al., 1998). Antibiotics in semen extender are added to overcome the growth of contaminated bacteria which is promoted by the presence of glucose in the extenders. The temperature range of 15 to $16^{\circ} \mathrm{C}$ also promotes the growth of most common Gram negative bacteria in the ejaculate. The addition of antibiotics at an appropriate concentration is needed for sperm survival during cryopreservation and this enhances pregnancy outcomes (Althouse et al., 2000; Gadea et al., 2003). Penicillin and streptomycin were the first used antibiotics in semen extender for cryopreservation. Later, antibiotic cocktail including tylosin $(50 \mu \mathrm{g})$, gentamicin $(250 \mu \mathrm{g})$, spectinomycin $(300 \mu \mathrm{g})$ and lincomycin $(150 \mu \mathrm{g})$ was used first time in long term bull semen extenders. Most recently, antibiotics like ceftiofur were also used in semen extenders and are being used, but there are no conclusive and evident results on resistance development (Gadea et al., 2003; Schulze et al., 2016).

\section{Why should antibiotics be replaced in semen extender preparation?}

Due to lack of hygienic standards in AI centers, the antibiotic usage is not regulated in many centers. To counteract the progress of antibiotic resistance in contaminant bacteria, there is a need of highly sophisticated hygienic standard management in AI centers and proper identification of hygienic critical control points (HCCP) (Schulze et al., 2017). Many alternates are there for antibiotics such as physical removal of bacteria during semen collection and processing time. Further alternatives are using single layer centrifugation, and to carry out the process in aseptic conditions. In very recent years, the use of antimicrobial peptides (AMPs) instead of antibiotics has been found to have great importance for the researchers as well in AI centers and cryobanks for better results (Dietrich et al., 2017). The disadvantage of using antibiotics and advantage of using antimicrobial peptides are represented in figure 1 . The antibiotic resistances in semen extenders were discussed by Morrell in articles (Morrell \& Wallgren, 2014; Morrell et al., 2016).

\section{Antimicrobial peptides (AMPs) and their functions}

Evolution has gifted every single organism with a wide variety of tools for survival. Evolution and natural selection are concurrent processes which helps human to develop innate mechanisms against microbial evolution. This scenario happens in microbes as well, making them more virulent. The shorter lifespan of microbes makes them accumulate more evolutionary changes than humans, thus giving the microbes a winning edge (Jerala \& Porro, 2004). AMPs are produced as first line of defence by human innate immunity system. For the first time, AMPs were initially isolated in 1980's from varieties of insects and frogs (Zasloff, 1987). After that, a large number of AMPs were identified and are in use for various clinical and medical applications. In general, AMPs possess different functions that cover a broad array of activities. While identifying AMPs in the initial days, researchers pointed that AMPs will have only bactericidal activity, but later found that AMPs also posses antifungal (De Lucca \& Walsh, 1999), antiviral (De Lucca \& Walsh, 1999), antitumor (Papo \& Shai, 2005), immunomodulatory activities (Mcphee \& Hancock, 2005). Many researchers claimed surprisingly a single AMP can exhibit all of these activities (Mcphee \& Hancock, 2005). $\beta$-defensins an antimicrobial peptide is the best example for immunomodulatory peptides which possess both innate and adaptive immune 


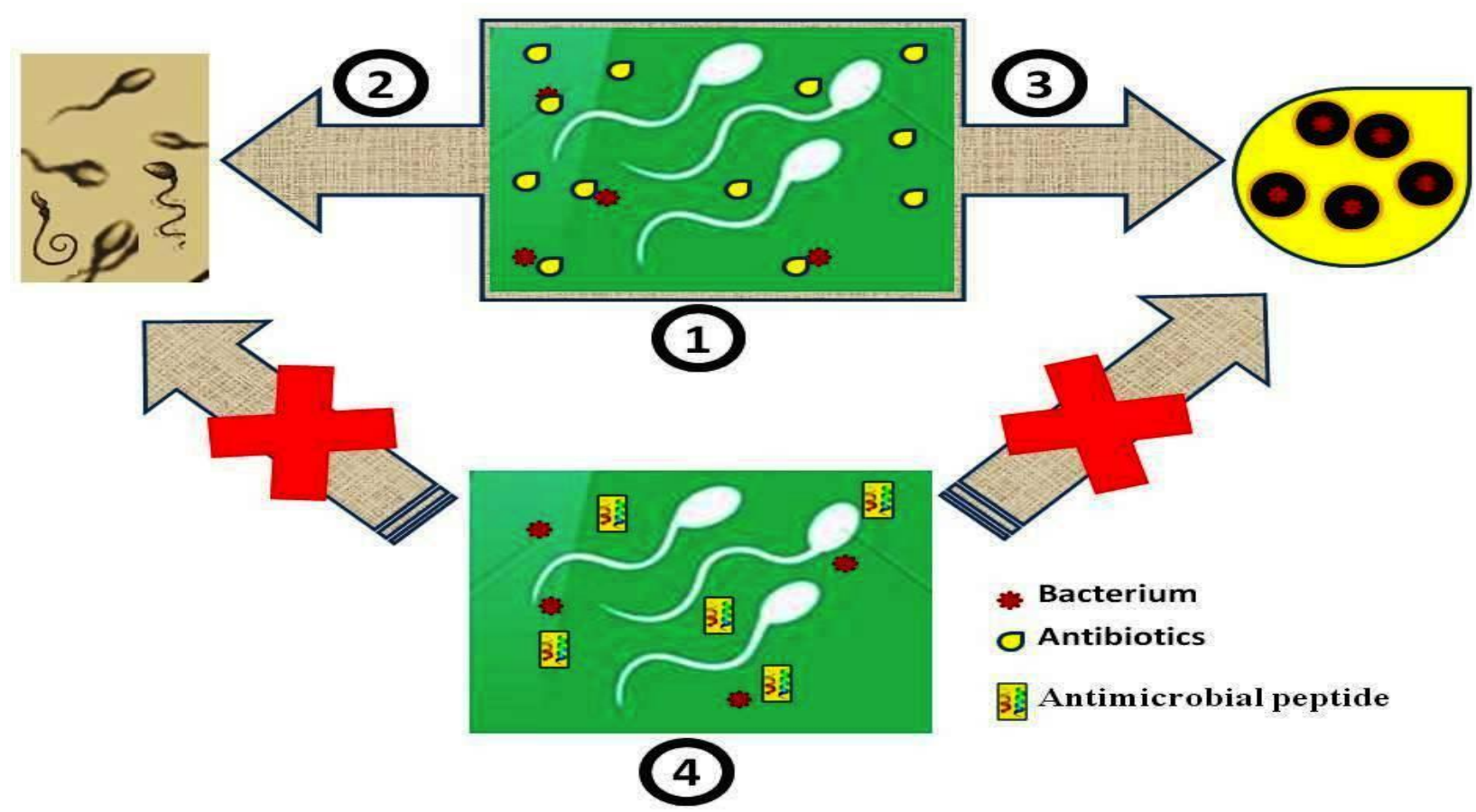

Figure 1: Antimicrobial peptides in semen extender wards off the disadvantages associated with conventional antibiotics usage. 1 - Conventional antibiotics in semen extender, 2- usage of antibiotics in semen extender leads to decreased semen quality, 3- usage of antibiotics results in evolution of antibiotic resistant bacteria, 4- replacement of conventional antibiotics in semen extenders with antimicrobial peptides makes development of antibiotic resistance a less possible event.

response, and they reveal direct antimicrobial activity (Dietrich et al., 2017).

\section{Uses of AMPs:}

The use of AMPs in semen extender was first used with the boar semen ejaculate, and antibiotic resistance was not reported in that case (Paulenz et al., 2000). The use of cyclic hexapeptides and synthetic magainin derivatives was also investigated by many researchers to be used in semen extenders for preserving boar andother species ejaculates (Coelho et al., 2017). The AMPs were found with little/no on eukaryotic cells, and this is the major prerequisite for the application of AMPs in semen extenders. Proteolytic stability, thermodynamic stability, bacterial selectivity and sensitivity, made hexapeptides as the best replacement for antibiotics in semen extenders for long time storage of semen samples especially for humans (Hall-Stoodley et al., 2012).

Many higher species including humans possess innate immune defense mechanisms, of which AMPs were found to be necessary components. The biological activity of each AMPs varies as the primary and secondary structure differences exhibited by the peptides affect their functionalities (Hall-Stoodley et al., 2012).
This is the crucial step that has to be focused while selecting AMP for the replacement of antibiotics in semen extenders. Conversely, the cationic charge and amphipathicity of AMPs were found to be conserved characteristics which explain its selective action on bacterial membranes that are highly negatively charged lipid molecules. Lysozyme isolated from human saliva (130 amino acids), by Alexander Fleming in 1922 still stands as the widely used antimicrobial protein of human origin, (Fleming, 1922).

Many peptides have been found to be rich in particular amino acids especially phenylalanine, tryptophan or arginine. For this reason the antimicrobial motifs in natural proteins, acts as potent candidates for designing selective and effective AMPs in clinical and medical applications (Chan et al., 2006). Many alternate methods were there to replace antibiotics in semen extender like doing Single Layer Centrifugation (SLC), carried out with more strict aseptic conditions may be very helpful in reducing the bacterial contamination (Morrell \& Wallgren, 2014), but this technique (SLC) has limitations too. The best alternative is to replace the antibiotics with AMPs in semen extenders. Many researchers have worked with different AMPs for substituting conventional antibiotics in semen extenders. Critical studies related to AMPs in semen extenders and their implications were tabulated in table 3 . 
Table 1 List of different semen extenders with its antibiotics used by researchers

\begin{tabular}{|c|c|c|c|}
\hline Semen extender used & Remarks & $\begin{array}{c}\text { Antibiotics used in semen } \\
\text { extender }\end{array}$ & Reference \\
\hline $\begin{array}{l}\text { TRIS Citrate } \\
\text { TRIS Milk }\end{array}$ & $\begin{array}{l}\text { Short term storage of Ram } \\
\text { semen }\end{array}$ & $\begin{array}{l}20 \mu \mathrm{M} \text { Penicillamine/ } 50 \mu \mathrm{g} \mathrm{mL}^{-1} \\
\text { of gentamicin }\end{array}$ & $\begin{array}{l}\text { Acharya et al., } \\
2017\end{array}$ \\
\hline $\begin{array}{l}\text { Many different extenders were used with } \\
\text { supplementation of ipoprotein fraction from } \\
\text { ostrich egg yolk }\end{array}$ & $\begin{array}{l}\text { Boar semen/ lipoprotein fraction } \\
\text { of ostrich egg yolk }\end{array}$ & $\begin{array}{l}50 \mu \mathrm{g} \mathrm{mL}^{-1} \text { of gentamicin is the } \\
\text { major antibiotic used in all the } \\
\text { different extenders }\end{array}$ & $\begin{array}{l}\text { Dziekonska et al., } \\
2017\end{array}$ \\
\hline $\begin{array}{l}\text { TRIS citrate, Milk, Soyabean with } \\
\text { Ringer's solution and Glucose solution 5\% }\end{array}$ & $\begin{array}{l}\text { Cocktail semen preservation } \\
\text { with mentioned semen extenders }\end{array}$ & $\begin{array}{l}70 \mu \mathrm{g} \mathrm{mL}^{-1} \text { of gentamicin and } \\
20 \mu \mathrm{M} \text { Penicillamine }\end{array}$ & $\begin{array}{l}\text { Schneider et al., } \\
2017\end{array}$ \\
\hline $\begin{array}{l}\text { Boars semen extender with soyabean and } \\
\text { lecithin }\end{array}$ & $\begin{array}{l}\text { Boars semen to check the quality } \\
\text { after addition of betaine in } \\
\text { semen extender }\end{array}$ & $\begin{array}{l}\text { Sperm parameters were } \\
\text { maintained with betaine with } \\
\text { addition of gentamicin antibiotics } \\
70 \mu \mathrm{g} \mathrm{mL}^{-1}\end{array}$ & Lugar et al., 2017 \\
\hline $\begin{array}{l}\text { Human semen extendes (E4), TRIS } \\
\text { extender with antioxidants }\end{array}$ & $\begin{array}{l}\text { Human semen extenders } \\
\text { supplemented with Tea } \\
\text { Polyphenol-T. Arjuna Bark, } \\
\text { antioxidant extender }\end{array}$ & $\begin{array}{l}\text { Penicillin-streptomycin } \\
50 \mu \mathrm{g} \mathrm{mL}^{-1}\end{array}$ & $\begin{array}{l}\text { Parameswari et al., } \\
2017\end{array}$ \\
\hline $\begin{array}{l}\text { Boar semen preservation, TRIS semen } \\
\text { extender }\end{array}$ & Boar semen & $\begin{array}{l}\text { Gentamicin varying concentration } \\
\text { with median } 220.37 \mathrm{mg} / \mathrm{L}\end{array}$ & Schulze et al., 2017 \\
\hline $\begin{array}{l}\text { Boar semen extenders, TRIS Semen } \\
\text { extenders }\end{array}$ & $\begin{array}{l}\text { Boar semen samples } \\
\text { preservation }\end{array}$ & $\begin{array}{l}\text { Replacement of antibiotics with } \\
\text { cationic antimicrobial peptides }\end{array}$ & Schulze et al., 2016 \\
\hline $\begin{array}{l}\text { Turkey, EK, Lake and Chicken semen } \\
\text { extenders, TRIS semen extenders }\end{array}$ & $\begin{array}{l}\text { Indian Red Jungle Fowl (Gallus } \\
\text { gallus murghi) }\end{array}$ & Gentamicin/penicillin $50 \mu \mathrm{g} \mathrm{mL}^{-1}$ & Rakha et al., 2016 \\
\hline $\begin{array}{l}\text { Two different egg yolk based semen } \\
\text { extenders and soybean lecithin based semen } \\
\text { extender }\end{array}$ & Bull semen samples & $\begin{array}{l}100000 \mathrm{IU} \text { penicillin, } 100 \mathrm{mg} \\
\text { streptomycin }\end{array}$ & $\begin{array}{l}\text { Abdussamad et al., } \\
2016\end{array}$ \\
\hline Boar semen extenders & $\begin{array}{l}\text { Liquid semen storage of boar } \\
\text { semen and effect of } \\
\text { bacteriospermia }\end{array}$ & Streptomycin $50 \mu \mathrm{g} \mathrm{mL}^{-1}$ & $\begin{array}{l}\text { Kuster \& Althouse, } \\
2016\end{array}$ \\
\hline Egg yolk and soybean extenders & $\begin{array}{l}\text { Evolution from egg yolk to } \\
\text { soybean-based extenders }\end{array}$ & Gentamicin/penicillin $50 \mu \mathrm{g} \mathrm{mL}^{-1}$ & Layek et al., 2016 \\
\hline egg yolk and soya milk-based extenders & $\begin{array}{l}\text { buffalo semen sample } \\
\text { cryopreservation }\end{array}$ & Streptomycin $50 \mu \mathrm{g} \mathrm{mL}^{-1}$ & $\begin{array}{l}\text { Chaudhari et al., } \\
2015\end{array}$ \\
\hline $\begin{array}{l}\text { Magnetized semen extenders containing } \\
\text { BSA }\end{array}$ & $\begin{array}{l}\text { Boar semen sample long time } \\
\text { preservation }\end{array}$ & Gentamicin/penicillin $50 \mu \mathrm{g} \mathrm{mL}^{-1}$ & Lee \& Park, 2015 \\
\hline Modified Beltsville extender & Rooster post-thaw semen quality & Streptomycin $50 \mu \mathrm{g} \mathrm{mL}^{-1}$ & Amini et al., 2015 \\
\hline $\begin{array}{l}\text { Four different semen extenders, TRIS, } \\
\text { soyabean, Lecithin, Milk based }\end{array}$ & $\begin{array}{l}\text { Human semen samples } \\
\text { preservation }\end{array}$ & $\begin{array}{l}\text { Gentamicin/Penicillin/ } \\
\text { Streptomycin } 50 \mu \mathrm{g} \mathrm{mL}^{-1}\end{array}$ & $\begin{array}{l}\text { Vickram et al., } \\
2015\end{array}$ \\
\hline Twelve different semen extenders & Boar semen samples & $\begin{array}{l}\text { Gentamicin/Penicillin/ } \\
\text { Streptomycin } 50 \mu \mathrm{gL}^{-1}\end{array}$ & Akandi et al., 2015 \\
\hline Soybean lecithin-based semen extender & Ram semen samples & $\begin{array}{l}\text { Streptomycin and different } \\
\text { antioxidants } 50 \mu \mathrm{gL}^{-1}\end{array}$ & Sharafi et al., 2015 \\
\hline Soybean-Based Extenders & Friesian Bull semen samples & $\begin{array}{l}\text { Gentamicin/Penicillin/ } \\
\text { Streptomycin } 50 \mu \mathrm{g} \mathrm{mL}^{-1}\end{array}$ & $\begin{array}{l}\text { Rehman et al., } \\
2014\end{array}$ \\
\hline $\begin{array}{l}\text { Different types of bovine and canine } \\
\text { commercial available semen extenders, } \\
\text { soyabean and lecithin semen extenders }\end{array}$ & Brown bear semen samples & Gentamicin $50 \mu \mathrm{g} \mathrm{mL}^{-1}$ & $\begin{array}{l}\text { Gomes-Alves et } \\
\text { al., } 2014\end{array}$ \\
\hline $\begin{array}{l}\text { plant-based soybean lecithin semen } \\
\text { extenders }\end{array}$ & Goat semen sample preservation & $\begin{array}{l}\text { Streptomycin and different } \\
\text { antioxidants } 62 \mu \mathrm{g} \mathrm{mL}^{-1}\end{array}$ & $\begin{array}{l}\text { Salmani et al., } \\
2014\end{array}$ \\
\hline
\end{tabular}


Table 2 Commercial semen extenders and the antibiotics used

\begin{tabular}{|lll|}
\hline Commercial successful semen extenders & Model for semen cryopreservation & \multicolumn{1}{c|}{ Antibiotics used } \\
\hline AndroPRO® Plus & synthetic long-term porcine semen extender & $\begin{array}{l}\text { Ampicillin, Apramycin, Enrofloxacin } \\
60 \mu \mathrm{g} \mathrm{mL}\end{array}$ \\
\hline AndroMed® & Long-term Bull semen extender & $\begin{array}{l}\text { Antibiotic cocktail includes Tylosin } 50 \mu \mathrm{g}, \\
\text { Gentamicin } 250 \mu \mathrm{g}, \text { Spectinomycin } 300 \mu \mathrm{g} \\
\text { and Lincomycin } 150 \mu \mathrm{g}\end{array}$ \\
\hline Triladyl@ \& Biladyl@ & Long-term Bovine semen extender & $\begin{array}{l}\text { Tylosin, Gentamicin, Spectinomycin, } \\
\text { Lincomycin }\end{array}$ \\
\hline EquiPRO CoolGuard & Long term Equine semen extender & Amikacin \& Penicillin \\
\hline Kobidil+ semen extender & $\begin{array}{l}\text { Short term semen extender for Boar semen } \\
\text { samples }\end{array}$ & Gentamycin sulphate 200 mg/L \\
\hline Beltsville semen extender & Short term semen extender & Gentamycin sulphate 250 mg/L \\
\hline Acromax semen extender & Long term Boar semen extender & $\begin{array}{l}\text { Lincomycin } 13.3 \mathrm{mg} / \mathrm{L} \text { and spectinomycin } \\
26.6 \text { mg/L }\end{array}$ \\
\hline
\end{tabular}

Table 3 Important studies related to antimicrobial peptides (AMP's) in semen extender and cryopreservation:

\begin{tabular}{|c|c|c|c|}
\hline Theme of the study & Implications & Conclusion & Reference \\
\hline $\begin{array}{l}\text { Can antimicrobial peptides be } \\
\text { an alternative for antibiotics in } \\
\text { semen extenders? }\end{array}$ & $\begin{array}{l}\text { There is a possibility of multi-bacterial } \\
\text { resistant in offspring via artificial } \\
\text { insemination (AI). Enormous steps have } \\
\text { been taken to employ AMPs to substitute } \\
\text { conventional antibiotics in semen } \\
\text { extenders }\end{array}$ & $\begin{array}{l}\text { Magainin and cyclic hexapeptides, } \\
\text { antimicrobial peptide derivates can } \\
\text { be used in boar semen extenders to } \\
\text { replace the existing conventional } \\
\text { antibiotics }\end{array}$ & Schulze et al., 2016 \\
\hline $\begin{array}{l}\text { Can cationic synthetic peptides } \\
\text { be used in semen extender for } \\
\text { cryopreservation? }\end{array}$ & $\begin{array}{l}\text { The antibacterial activity of two types of } \\
\text { cyclic synthetic peptides (c-WWW, c- } \\
\text { WFW) and one helical peptide called } \\
\text { magainin II against Gram-positive and } \\
\text { Gram-negative bacteria }\end{array}$ & $\begin{array}{l}\text { These antimicrobial peptides, not a } \\
\text { complete alternative to conventional } \\
\text { antibiotics and still to avoid multi- } \\
\text { strain resistant. Cyclic and helical } \\
\text { peptides may be the possible } \\
\text { alternative for antibiotics in boar } \\
\text { semen preservation }\end{array}$ & Speck et al., 2014 \\
\hline $\begin{array}{l}\text { hCAP-18 (human cationic } \\
\text { antimicrobial peptides } \\
\text { produced from epithelium of } \\
\text { epididymis and contributes } \\
\text { counter immunity against } \\
\text { female reproductive tract } \\
\text { bacteria }\end{array}$ & $\begin{array}{l}\text { By immunohistochemistry, hCAP- } 18 \text { was } \\
\text { able to detect in the epididymis and not in } \\
\text { the testis. hCAP- } 18 \text { was found to have } \\
\text { antibacterial activity against broad } \\
\text { spectrum of bacteria }\end{array}$ & $\begin{array}{l}\text { This hCAP-18 antimicrobial peptide } \\
\text { can probably use in many medical } \\
\text { applications including } \\
\text { cryopreservation }\end{array}$ & Malm et al., 2000 \\
\hline $\begin{array}{l}\text { Processing of hCAP- } 18 \text { to } \\
\text { ALL-38 antimicrobial peptides } \\
\text { in female reproductive tract }\end{array}$ & $\begin{array}{l}\text { Seminal plasma antimicrobial peptide } \\
\text { hCAP- } 18 \text { was further processed to } \\
\text { generate a } 38 \text { amino acid antimicrobial } \\
\text { peptide called ALL- } 38 \text { by gastricsin }\end{array}$ & $\begin{array}{l}\text { ALL-38 was found to possess } \\
\text { antibacterial activity against a wide } \\
\text { range of bacteria. Further, it protects } \\
\text { from infection after sexual } \\
\text { intercourse }\end{array}$ & Sorensen et al., 2003 \\
\hline $\begin{array}{l}\text { Is GL13K- an antimicrobial } \\
\text { peptide are effective against } \\
\text { Pseudomonas aeruginosa }\end{array}$ & $\begin{array}{l}\text { GL13NH2 was not showing any } \\
\text { bactericidal activity, later it was } \\
\text { introduced with three lysine residues and } \\
\text { converted into an active antimicrobial } \\
\text { peptide called GL13K }\end{array}$ & $\begin{array}{l}\text { GL13K- an antimicrobial peptide } \\
\text { found to be very active against } \\
\text { Pseudomonas aeruginosa }\end{array}$ & Hirt \& Gorr, 2013 \\
\hline $\begin{array}{l}\text { Is Semenogelin derived } \\
\text { antimicrobial peptides protects } \\
\text { spermatozoa? }\end{array}$ & $\begin{array}{l}\text { Cationic antimicrobial peptide was } \\
\text { derived from Semenogelin protein }\end{array}$ & $\begin{array}{l}\text { It poses number of applications } \\
\text { including antibacterial and antiviral } \\
\text { activity could be used in semen } \\
\text { extenders }\end{array}$ & Bourgeon et al., 2004 \\
\hline
\end{tabular}

Journal of Experimental Biology and Agriculture Science http://www.jebas.org 


\section{Cationic antimicrobial peptides (CAMPs):}

Cationic antimicrobial peptides exert direct antibacterial and antifungal activity. It also possesses various biological functions like inhibition of lipopolysaccharide related inflammatory, immunomodulation and immunosuppressant activity (Mulder et al., 2013). Along with the above mentioned functions, antibiotic resistance evolution in using conventional antibiotics makes cationic antimicrobial peptides a better replacement for conventional antibiotics in semen extenders for cryopreservation (Zasloff, 2016). It was found that $80-85 \%$ of the infections were with biofilm etiology in the United States (Fux et al., 2003; Davies et al., 2006). Extracellular matrix along with low growth rates associated with biofilms necessitates a 10 to 1000 fold higher concentrations of antibiotics to curtail bacterial growth (Hawkey, 2008). Antibiotic resistance among medically important microbes is on rising, and this also adds to the existing challenge (Boucher et al., 2009).

CAMPs were seen as a potential alternates to deal with the problem of antibiotic resistance development and biofilms (Schulze et al., 2014; Speck et al., 2014). In comparison to traditional antibiotics, CAMPs lower the probability of microbial resistance. Antigenic sites on bacterial membranes change as a result of antibiotic resistance evolution and less specific activity expressed by CAMPs on bacterial membranes makes development of resistance against CAMPs in bacteria impossible (Yenugu et al., 2004). This circumvents the restriction of many traditional antibiotics that require bacterial growth (Ernst \& Peschel, 2007). Bradshaw discussed issues for potential clinical use of CAMPs (Bradshaw, 2003). The conception that CAMP may not possess broad-spectrum activity was found wrong. Ambicin, gramicidin $\mathrm{S}$ are found to be the best examples for broad spectrum activity of antimicrobial peptides. Researchers showed that 13-amino-acid peptide GL13K exhibited low toxicity and broad antibacterial activity against mammalian cells and planktonic bacteria, respectively (Abdolhosseini et al., 2012). GLK13K is effective against Pseudomonas aeruginosa biofilms formed on pegs of a Calgary device, associated with a static biofilm system (Ceri et al., 1999). Overall, Ceri results showed that a $99.9 \%$ reduction in bacterial cell numbers in a 4 -h treatment with $100 \mu \mathrm{g} / \mathrm{mL}$ concentration of this GLK13K. These results support the usage of GLK13K in human and animal semen preservation in extenders instead of standard antibiotics. Biofilm growth can be inhibited/controlled by employing mechanical forces, which is not possible in cryopreservation process. Hence the use of CAMPs is greatly realized. More specifically, CAMPs are highly sensitive to physiological salt concentrations. In turn, this high sensitivity limits the utilization of CAMPs in biological fluids (Goldman \& Widom, 1997).
Two different synthetic cationic antimicrobial peptides like cWWW and c-WFW which belongs to cyclic hexapeptide group were investigated with boar semen extender for cryopreservation (Speck et al., 2014). Speck used a synthetic helical amide analog, magainin II (MK5E), for boar semen sample preservation invitro. This was found to be effective against gram positive and gram negative micro flora found in boar semen.. In this study boar semen samples were initially maintained only with Beltsville Thawing Solution (BTS) with $250 \mu \mathrm{g} / \mathrm{mL}$ gentamicin which is treated as a control group. Boar semen samples were then grouped into three like BTS+c-WWW, BTS+c-WFW, and BTS+MK5E. Minimum inhibitory concentration (MIC) for all the AMPs was done using broth microdilution technique (Speck et al., 2014). The author concludes that both c-WWW and c-WFW was showing activity against almost all bacteria in liquid preserved boar semen samples. Speck et al finds that antimicrobial peptides in semen extenders would be a better replacement for conventional antibiotics and it will lead to limit the selection of multi-resistant strains (Speck et al., 2014).

\section{Human parotid secretory protein associated AMPs in semen extender:}

Human parotid secretory protein (PSP) which is found to have structural similarity with bactericidal, and two potential proteins, permeability-increasing protein, and lipopolysaccharide binding protein, could be possibly used in semen extender (Abdolhosseini et al., 2012). These two peptides were found as potential antimicrobial peptides and the sequence information was identified from PSP. This could be more relevant replacement option, as it is found to have structural similarity with lipopolysaccharide binding protein, as prostasomes were rich in lipid content and played a significant role in motility (Schiessel, 2003). Helmut Hirt derived a 13-amino acid peptide called GL13K, from human PSP. Initially, the antimicrobial and various functions of this particular protein was attributed to amino acid residues 141 to 153 of PSP $\left(\mathrm{GL}_{13 \mathrm{NH}_{2}}\right)$ (Hirt \& Gorr, 2013; Chen et al., 2014). This peptide was found to have the property of aggregating both Gram-negative and Gram-positive bacteria and capable of binding with LPS, but many times the peptide lacks bactericidal activity.

GL13K derived its name from the replacement of charged aminoacids in $5^{\text {th }}$ and $11^{\text {th }}$ position by lysine $(\mathrm{K})$ residues. This replacement event confers bactericidal activity to the AMP but prevents it from acting as a bacterium agglutinating agent. Researchers found that this GL13K was also active against bacteria in biofilm communities as well as monospecies (Bingle \& Gorr, 2004). GL13K was reported to significantly reduce the cell count in biofilms grown either under aerobic or anaerobic conditions. So, as per these results, GL13K could be the source 
antimicrobial peptide that can be added in the semen extender to replace antibiotics (Hirt \& Gorr, 2013).

\section{Male and female genital tract derived AMPs}

Mammalian organs synthesized several types of antimicrobial peptides with multi-functionalities. Amongst them, the most focused areas are the epithelial layer of skin, and entire digestive, respiratory and reproductive tracts (Zhang et al., 2000; Gallo et al., 2002; Boman, 2003). Compared to any other tract, genital tract of human males and females produces enormous endogenous proteins and peptides which have anti-infectious characteristics. In humans, the most studied cationic AMP's are $\beta$-defensins and cathelicidins (Frew \& Stock, 2011). Defensins contain a series of cysteine molecules that are considered as part of immune defense system, in the genital tract. Many $\beta$-defensins are synthesized mainly in the epithelial cells of epididymis during sperm maturation, later released into the lumen, finally detected on the surface of sperm membrane (Com et al., 2003). This attachment refers to not only the function of antimicrobial activity but also in the proper function of fertilization. In a study, defensin depleted mutant spermatozoa was found with impaired motility, morphology, a destabilized microtubule structure and finally results in infertility (Zanich et al., 2003; Zhou et al., 2004).

The precursor protein hCAP18, which is considered to be the only representative for antimicrobial activity from the human male genital tract, was predominantly synthesized in the epididymis (Hammami-Hamza et al., 2001). CAP18 molecules have also been identified in head, tail and neck region of the sperm cell as well in seminal plasma. The majority of hCAP18 proteins were associated with proteasomes. The primary functions of the prostasomes were sperm cell-proteasome interaction, enhancing sperm cell rapid motility, induction of sperm cell capacitation, induction of acrosome reaction and finally the fertilization (Gombart et al., 2005). So, once the sperm cells are deposited in the female reproductive tract, though the cell may be matured to fuse with the ova, it requires many series of reactions in order to fertilize. Prostasomes fulfilled these series of steps in female reproductive tract. Prostasomes are rich in cholesterolphospholipid ratio. Therefore it is opined that during fusion event of prostasomes with spermatozoa, the protein like hCAP18 which is present on the surface will also be transferred along with cholesterol to the sperm cell membrane and here the transport is mediated by the sperm into the uterus. Once the proteolytic processing of hCAP18 was over, the AMP LL-37 get released from the precursor protein. When it was releasing, the disruptive nature of this peptides were protected by the cholesterol enrichment in the sperm membrane (Yarbrough et al., 2014). This particular antimicrobial peptide can also be isolated from the male genital tract and can be processed to use in the semen extender for cryopreservation of sperm cells against contamination produced by many bacteria as well to maintain the integrity of sperms (Ciornei et al., 2003). Many antimicrobial peptides were synthesized by sperm cells and seminal plasma and transferred to the female reproductive tract, but female reproductive tract itself is also capable of synthesizing some antimicrobial peptides to evade the pathogens and immunomodulatory functions. Lipophilin, an antimicrobial peptide derived from female reproductive tract (FRT) showed broad spectrum activity. This type of peptide can also be used in semen extender during cryopreservation (Dcruz et al., 1995).

\section{Development of AMPs resistant pathogens:}

There are some bacteria which are resistant to even AMPs through many mechanisms. The major mechanism of getting resistance is through the selective production of bacterial proteases (Hashemi et al., 2017). After the penetration, peptides are very prone for transportation outside the cell through the energy-dependent mechanism and finally resided at the cytoplasmic membrane of bacteria. In addition to this, the formation of extracellular polymers as a biofilm further makes the microbes insensitive to AMP effects. A study was conducted with pexiganan and reported that resistance of AMPs was predicted when some bacterial population is regularly exposed with AMPs (Perron et al., 2006). These types of reports put many questions on researchers and on ART professionals to include AMPs in semen extender and its practices, but there is no timescale limit to predict the development of AMP resistant pathogens (Van Nierop et al., 2008).

\section{Plant-derived AMPs:}

AMPs can also be isolated from different plant species, within those different parts including flowers, leaves, fruits, roots, tubers, and especially seeds (Pelegrini et al., 2008; Benko-Iseppon et al., 2010; Silva et al., 2011; Astafieva et al., 2013; Singha et al., 2016). Plant-derived AMPs have many characteristic features in common that includes, low molecular mass, amphipathic properties, net positive charge at physiological $\mathrm{pH}$, having more repeats of cysteine residues connected in pairs forming disulfide bridges, resulting in stable peptides (Astafieva et al., 2013). These types of AMPs have an explicit interaction with particular cellular membranes and active against certain pathogens, with these properties, AMPs from capsicum have some role in preventing the infections of various pathogens evading. Different fractions of enriched peptides have been isolated from capsicum including PEF1, PEF2, and PEF3 that exhibited a potent antifungal activity against different yeasts (Dias et al., 2013). The N-terminal sequence of these peptides was shown with highest similarity level with serine protease inhibitors (SPI) when analyzed through proper database systems. Taveira et al. identified a protein that is equal to the compound thionin from capsicum that has severe 
antifungal and antibacterial activity, and this shows effective therapeutic reactions against Candida species (Taveira et al., 2014; Taveira et al., 2016). In this research, the author concluded that antimicrobial peptides isolated and purified from capsicum demonstrated in vitro inhibitory activity against a range of fungi and sometimes with bacteria of agronomic importance.

\section{Conclusions}

Antibiotics are said to be the mandatory component while preparing semen extender for cryopreservation. High level increase in the resistance rate against conventional antibiotics in semen extenders demands an alternative for antibiotics in semen extender. In this review, we suggest that the only best alternative to traditional antibiotics is antimicrobial peptides in semen extender. Especially, the antimicrobial peptides derived from male and female genital tract could be the best peptides that render the antibiotic functions in semen extender.

\section{Acknowledgements:}

All the authors acknowledge and thank their respective Institutes and Universities. Dr. Vickram A S is thankful to Department of science and technology DST-SERB, govt. of India for supporting financially during this period through young scientist scheme. The related authors were also thankful to Ms. Vyshali for their valuable lingual corrections. Dr K Dhama and prof. Hafiz MN Iqbal thanks their respective Institutes.

\section{Conflicts of interest:}

All authors declare that there exist no commercial or financial relationships that could in any way lead to a potential conflict of interest.

\section{References}

Abdolhosseini MJ, Ulm FJ, Pellenq RJM (2012) Evidence on the dual nature of aluminum in the calcium-silicate-hydrates based on atomistic simulations. Journal of the American Ceramic Society 95 : 1128-1137.

Abdussamad AM, Detterer J, Gauly M, Holtz W (2016) Comparison of various semen extenders and addition of prostaglandin F $2 \alpha$ on pregnancy rate in cows. Animal $10: 655-659$

Acharya M, Burke JM, Hansen C, Rorie RW (2017) Evaluation of semen extenders for short-term storage of ram semen at $4^{\circ} \mathrm{C}$. Reproduction, Fertility and Development 29 : 118-118.

Akandi A, Ugwu SO, Machebe NS (2015) Survivability of boar sperm stored under room temperature in extenders containing some natural products. Open Access Animal Physiology 7: 57-64.

Althouse GC, Kuster CE, Clark SG, Weisiger RM (2000) Field investigations of bacterial contaminants and their effects on extended porcine semen. Theriogenology $53: 1167-1176$.

Amini MR, Kohram H, Zare-Shahaneh A, Zhandi M, Sharideh H, Nabi MM (2015) The effects of different levels of catalase and superoxide dismutase in modified Beltsville extender on rooster post-thawed sperm quality. Cryobiology $70: 226-232$.

Astafieva AA, Rogozhin EA, Andreev YA, Odintsova TI, Kozlov SA (2013) A novel cysteine-rich antifungal peptide ToAMP4 from Taraxacum officinale Wigg. flowers. Plant physiology and Biochemistry 70: 93-99.

Baltzer S, Brown MH (2011) Antimicrobial peptides: promising alternatives to conventional antibiotics. Journal of Molecular Microbiology and Biotechnology $20: 228-235$.

Benko-Iseppon AM, Lins Galdino S, Calsa J, Akio Kido E, Tossi A, Carlos L, Crovella S (2010) Overview on plant antimicrobial peptides. Current Protein and Peptide Science 11 : 181-188.

Bingle CD, Gorr SU (2004) Host defense in oral and airway epithelia: chromosome 20 contributes a new protein family. The International Journal of Biochemistry \& Cell Biology $36: 2144-2152$

Boman HG (2003) Antibacterial peptides: basic facts and emerging concepts. Journal of Internal Medicine 254 : 197-215.

Boucher HW, Talbot GH, Bradley JS, Edwards JE, Gilbert D, Rice LB, Scheld M, Spellberg B, Bartlett J (2009) Bad bugs, no drugs: no ESKAPE! An update from the Infectious Diseases Society of America. Clinical Infectious Diseases 48: $1-12$

Bourgeon F, Evrard B, Brillard-Bourdet M, Colleu D, Jegou B, Pineau C (2004) Involvement of semenogelin-derived peptides in the antibacterial activity of human seminal plasma. Biology of Reproduction 70 : 768-774.

Bradshaw JP (2003) Cationic antimicrobial peptides-Issues for potential clinical use. Biodrugs 17 : 233-240.

Brown K, Hancock RE (2006) Cationic host defense (antimicrobial) peptides. Current Opinion in Immunology $18: 24-30$.

Bussalleu E, Sancho S, Briz MD, Yeste M, Bonet S (2017) Do antimicrobial peptides PR-39, PMAP-36 and PMAP-37 have any effect on bacterial growth and quality of liquid-stored boar semen? Theriogenology 89: 235-243.

Ceri H, Olson ME, Stremick C, Read RR, Morck D, Buret A (1999) The Calgary Biofilm Device: new technology for rapid determination of antibiotic susceptibilities of bacterial biofilms. Journal of Clinical Microbiology 37 : 17711776.

Chan DI, Prenner EJ Vogel HJ (2006) Tryptophan-and arginine-rich antimicrobial peptides: structures and mechanisms of action. Biochimica et Biophysica Acta (BBA)-Biomembranes 175 : 1184-1202.

Chaudhari DV, Dhami AJ, Hadiya KK, Patel JA (2015) Relative efficacy of egg yolk and soya milk-based extenders for cryopreservation $\left(-196{ }^{\circ} \mathrm{C}\right)$ of buffalo semen. Veterinary World $8: 239$.

Chen X, Hirt H, Li Y, Gorr SU, Aparicio C (2014) Antimicrobial GL13K peptide coatings killed and ruptured the wall of Streptococcus gordonii and prevented formation and growth of biofilms. PloS one 9: e111579.

Ciornei CD, Egesten A, Bodelsson M (2003) Effects of human cathelicidin antimicrobial peptide LL-37 on lipopolysaccharide-induced nitric oxide release from rat aorta in vitro. Acta Anaesthesiologica Scandinavica 47 : 213-220.

Coelho ML, Duarte AFS, Bastos MCF (2017) Bacterial labionin-containing peptides and sactibiotics: unusual types of antimicrobial peptides with potential use in clinical settings (a review). Current Topics in Medicinal Chemistry 17: 122.

Com E, Bourgeon F, Evrard B, Ganz T, Colleu D, Jegou B (2003) Expression of antimicrobial defensins in the male reproductive tract of rats, mice, and humans. Biology of Reproduction 68 : 95-104

Da Costa P, Loureiro M, Matos AJ (2013) Transfer of multidrug-resistant bacteria between intermingled ecological niches: the interface between humans, 
animals and the environment. International Journal of Environmental Research and Public Health $10: 278-294$.

Davies J, Spiegelman GB, Yim G (2006) The world of subinhibitory antibiotic concentrations. Current Opinion in Microbiology 9 : 445-453.

Dcruz OJ, Pereira H, Hass GG (1995) Sperm Immobilizing Activity of a Synthetic Bioactive Peptide 20-44 of 37-kDa Cationic Antimicrobial Protein (CAP37) of Human Neutrophils. Journal of Andrology 16 : 432-440

De Lucca AJ, Walsh TJ (1999) Antifungal peptides: novel therapeutic compounds against emerging pathogens. Antimicrobial Agents and Chemotherapy $43: 1-11$.

Dias GB, Gomes VM, Pereira UZ, Ribeiro SF, Carvalho AO, Rodrigues R, Machado OL, Fernandes KV, Ferreira AT, Perales J, Da Cunha M (2013) Isolation, characterization and antifungal activity of proteinase inhibitors from Capsicum chinense Jacq. seeds. The Protein Journal 32 : 15-26.

Dietrich MA, Irnazarow I, Ciereszko A (2017) Proteomic identification of seminal plasma proteins related to the freezability of carp semen. Journal of Proteomics 162: 52-61

Dziekonska A, Kinder M, Frase L, Strzeżek J, Kordan W (2017) Metabolic activity of boar semen stored in different extenders supplemented with ostrich egg yolk lipoproteins. Journal of Veterinary Research 61 : 127-133.

Ernst CM, Peschel A (2011) Broad-spectrum antimicrobial peptide resistance by MprF-mediated aminoacylation and flipping of phospholipids. Molecular Microbiology 80 : 290-299.

Fleming A (1922) On a remarkable bacteriolytic element found in tissues and secretions. Proceedings of the Royal Society of London B: Biological Sciences 93 : 306-317.

Foote RH (2002) Within-herd Use of Boar Semen at $5{ }^{\circ} \mathrm{C}$, with a Note on Electronic Monitoring of Oestrus. Reproduction in domestic animals 37 : 61-63.

Frew L, Stock SJ (2011) Antimicrobial peptides and pregnancy. Reproduction $141: 725-735$.

Fux C, Stoodley P, Hall-Stoodley L, Costerton JW (2003) Bacterial biofilms: a diagnostic and therapeutic challenge. Expert Review of Anti-Infective Therapy $1: 667-683$

Gadea J (2003) semen extenders used in the artificial inseminarion of swine. Spanish Journal of Agricultural Research 1 : 17-27.

Gallo RL, Murakami M, Ohtake T, Zaiou M (2002) Biology and clinical relevance of naturally occurring antimicrobial peptides. Journal of Allergy and Clinical Immunology 110 : 823-831.

Giuliani A, Pirri G, Nicoletto S (2007) Antimicrobial peptides: an overview of a promising class of therapeutics. Open Life Sciences 2 : 1-33.

Goldman R, Widom J (1997) Dataguides: Enabling query formulation and optimization in semistructured databases. Stanford.

Gombart AF, Borregaard N, Koeffler HP (2005) Human cathelicidin antimicrobial peptide (CAMP) gene is a direct target of the vitamin D receptor and is strongly up-regulated in myeloid cells by 1,25-dsihydroxyvitamin D3. The Federation of American Societies for Experimental Biology Journal 19 : 1067-1077.

Gomes-Alves S, Alvarez M, Nicolas M, Lopez-Uruena E, Martínez-Rodríguez C, Borragan S, Anel L (2014) Use of commercial extenders and alternatives to prevent sperm agglutination for cryopreservation of brown bear semen. Theriogenology $82: 469-474$.

Hall-Stoodley L, Stoodley P, Kathju S, Hoiby N, Moser C, William Costerton J Bjarnsholt T (2012) Towards diagnostic guidelines for biofilm-associated infections. FEMS Immunology \& Medical Microbiology 65 : 127-145.

Hammami-Hamza S, Doussau M, Bernard J, Rogier E, Duquenne C, Richard Y (2001) Cloning and sequencing of SOB3, a human gene coding for a sperm protein homologous to an antimicrobial protein and potentially involved in zona pellucida binding. Molecular human reproduction $7: 625-632$

Hancock RE, Sahl HG (2006) Antimicrobial and host-defense peptides as new anti-infective therapeutic strategies. Nature Biotechnology 24 : 1551-1557.

Hashemi MM, Rovig J, Weber S, Hilton B, Forouzan MM, Savage PB (2017) Susceptibility of colistin-resistant, Gram-negative bacteria to antimicrobial peptides and ceragenins. Antimicrobial Agents and Chemotherapy AAC: 00292

Hawkey PM (2008) Prevalence and clonality of extended-spectrum $\beta$-lactamases in Asia. Clinical Microbiology and Infection 14 : 159-165.

Hirt H, Gorr SU (2013) Antimicrobial peptide GL13K is effective in reducing biofilms of Pseudomonas aeruginosa. Antimicrobial Agents and Chemotherapy 57 : 4903-4910.

Jerala R, Porro M (2004) Endotoxin neutralizing peptides. Current Topics in Medicinal Chemistry 4 : 1173-1184.

Kuster CE, Althouse GC (2016) The impact of bacteriospermia on boar sperm storage and reproductive performance. Theriogenology 85(1): 21-26.

Layek SS, Mohant TK, Kumaresan A, Parks JE (2016) Cryopreservation of bull semen: evolution from egg yolk based to soybean based extenders. Animal Reproduction Science 172: 1-9.

Lee SH, Park CK (2015) Antioxidative effects of magnetized extender containing bovine serum albumin on sperm oxidative stress during long-term liquid preservation of boar semen. Biochemical and Biophysical Research Communications 464 : 467-472.

Lugar DW, Krom WA, Proctor JA, Mings PD, Stewart KR (2017) Effects of supplemental betaine to semen extenders on semen quality in boars. Journal of Animal Science 95(supplement2): 34-34

Malm J, Sorensen O, Persson T, Frohm-Nilsson M, Johansson B, Bjartell A, Egesten A (2000) The human cationic antimicrobial protein (hCAP-18) is expressed in the epithelium of human epididymis, is present in seminal plasma at high concentrations, and is attached to spermatozoa. Infection and Immunity $68: 4297-4302$.

Martin L, Munoz OM, De Cupere EC, Van Driessche F, Echemendia-Blanco E, Rodríguez D (2010). Bacterial contamination of boar semen affects the litter size. Animal Reproduction Science 120:95-104.

Mcphee JB, Hancock RE (2005) Function and therapeutic potential of host defence peptides. Journal of Peptide Science 11 : 677-687.

Morrell JM, Wallgren (2014) Alternatives to antibiotics in semen extenders: a review. Pathogens 3 : 934-946

Morrell JM (2016) Antimicrobials in Boar Semen Extenders - A Risk/Benefit Analysis. Journal of Antimicrobial Agents 2 : 1-3. 1:107.

Mulder KC, Lima LA, Miranda VJ, Dias SC, Franco OL (2013) Current scenario of peptide-based drugs: the key roles of cationic antitumor and antiviral peptides. Frontiers in Microbiology 4: 18-24

Papo N, Shai Y (2005) Host defense peptides as new weapons in cancer treatment. Cellular and Molecular Life Sciences 62 : 784-79.

Parameswari R, Rao KA, Manigandan P, Vickram AS, Archana K, Sridharan TB (2017) Tea Polyphenol-T. Arjuna Bark As Sperm Antioxidant Extender in Infertile Smokers. CryoLetters 38 : 95-99.

Paulenz H, Kommisrud E, Hofmo PO (2000) Effect of long-term storage at different temperatures on the quality of liquid boar semen. Reproduction in Domestic Animals $35: 83-87$.

Pelegrini PB, Murad AM, Silva LP, Dos Santos RC, Costa FT, Tagliari PD, Bloch Jr C, Noronha EF, Miller RN, Franco OL (2008) Identification of a novel storage glycine-rich peptide from guava (Psidium guajava) seeds with activity against Gram-negative bacteria. Peptides 29 : 1271-1279. 
Perron GG, Zasloff M, Bell G (2006) Experimental evolution of resistance to an antimicrobial peptide. Proceedings of the Royal Society of London B: Biological Sciences 273 : 251-256.

Plisko NT (1965) A method of prolonging the viability and fertilizing ability for boar spermatozoa. Svinovodstvo 19: 37.

Rakha BA, Ansari MS, Hussain I, Anwar M, Akhter S, Blesbois E (2016) Comparison of extenders for liquid storage of Indian Red Jungle Fowl (Gallus gallus murghi) spermatozoa. Avian Biology Research 9 : 207-212.

Rehman FU, Qureshi MS, Khan RU (2014) Effect of soybean based extenders on sperm parameters of Holstein-Friesian bull during liquid storage at $4^{\circ} \mathrm{C}$. Pakistan Journal of Zoology 46 : 185-189.

Rillo SM, Shokouhi V, Boix EG, Hernandez-Gi R, Romero L (1998) Contamination of semen doses and its possible relationship with the bacterial flora of the prepuce. In Proceedings of 15th IPVS Congress, Birmingham, England.

Roca I, Akova M, Baquero F, Carlet J, Cavaleri M, Coenen S, Cohen J, Findlay D, Gyssens I, Heure OE, Kahlmeter G (2015) The global threat of antimicrobial resistance: science for intervention, New Microbes and New Infections 6: 22 29.

Salman H, Towhidi A, Zhandi M, Bahreini M, Sharafi M (2014) In vitro assessment of soybean lecithin and egg yolk based diluents for cryopreservation of goat semen. Cryobiology $68: 276-280$.

Schiessel H (2003) The physics of chromatin. Journal of Physics: Condensed Matter 15 : R699.

Schneider H, Fischer D, Failing K, Ehling C, Meinecke-Tillmann S, Wehrend A, Lierz M (2017) Investigations on different semen extenders for cockatiel semen. Journal of Zoo Biology $1: 13-17$

Schulze CC, Junkes M, Mueller C, Speck P, Ruediger S, Dathe K, Mueller K (2014) Effects of cationic antimicrobial peptides on liquid-preserved boar spermatozoa. PloS one 9 : e100490.

Schulze M, Ammon C, Rudiger K, Jung M, Grobbel M (2015) Analysis hygienic critical control points in boar semen production. Theriogenology 83 : 430-437.

Schulze M, Dathe M, Waberski D, Mulle K (2016) Liquid storage of boar semen: Current and future perspectives on the use of cationic antimicrobial peptides to replace antibiotics in semen extenders. Theriogenology 85: $39-46$.

Schulze M, Grobbel M, Riesenbeck A, Brüning S, Schaefer J, Jung M, Grossfeld R (2017) Dose rates of antimicrobial substances in boar semen preservation-time to establish new protocols. Reproduction in Domestic Animals $52: 397-402$.

Seo M, Won HS, Kim JH, Mishig-Ochir T, Lee BJ (2012) Antimicrobial peptides for therapeutic applications: A review. Molecules 17: 12276-12286.

Sharafi M, Zhandi M, Sharif AA (2015) Supplementation of soybean lecithinbased semen extender by antioxidants: complementary flowcytometric study on post-thawed ram spermatozoa. Cell and Tissue Banking 16: 261-269.

Silva ON, Mulder KC, Barbosa AE, Otero-Gonzalez AJ, Lopez-Abarrategui C, Rezende TM, Dias SC, Franco OL (2011) Exploring the pharmacological potential of promiscuous host-defense peptides: from natural screenings to biotechnological applications. Frontiers in Microbiology 2: 232

Singha SK, Vermaa S, Verma PK (2016) Genetically Engineered Crops Against Bacterial and Fungal Diseases: A War of Attrition. Current Developments in Biotechnology and Bioengineering: Crop Modification, Nutrition, and Food Production 125.
Sorensen OE, Gram L, Johnsen AH, Andersson E, Bangsboll S, Tjabringa GS, Borregaard N (2003) Processing of Seminal Plasma hCAP-18 to ALL-38 by Gastricsin a novel mechanism of generating antimicrobial peptides in vagina. Journal of Biological Chemistry 278 : 28540-28546.

Speck S, Courtiol A, Junkes C, Dathe M, Müller K, Schulze M (2014) Cationic synthetic peptides: assessment of their antimicrobial potency in liquid preserved boar semen. PloS one 9 : e105949.

Taveira GB, Carvalho AO, Rodrigues R, Trindade FG, Da Cunha M, Gomes VM (2016) Thionin-like peptide from Capsicum annuum fruits: mechanism of action and synergism with fluconazole against Candida species. BioMed Central (BMC) microbiology 16: 12.

Taveira GB, Mathias LS, Motta OV, Machado OL, Rodrigues R, Carvalho AO (2014) Thionin-like peptides from Capsicum annuum fruits with high activity against human pathogenic bacteria and yeasts. Peptide Science 102 : 30-39.

Tiwari R, Chakraborty S, Dhama K, Rajagunalan S, Singh SV (2013) Antibiotic resistance- an emerging health problem: causes, worries, challenges and solutions - a review. International Journal of Current Research $5: 1880$ 1892.

Van Nierop SN, Axcell BC, Cantrell IC, Rautenbach M (2008) Optimised quantification of the antiyeast activity of different barley malts towards a lager brewing yeast strain. Food microbiology $25: 895-901$.

Vickram AS, Rao KA, Archana K, Jayaraman G, Kumar S, Sridharan TB (2015) Effects of Various Semen Extenders on Semen Parameters for the Purpose of Human Male Fertility Preservation. Cryoletters 36 :182-6.

Westendorf P, Richte L, Treu H (1975) Deep freezing of boar sperma. Laboratory and insemination results using the Huilsenberger paillete method. DTW. Deutsche tierütliche Wochenschrift $82: 261$

WHO (2014) Antimicrobial resistance: global report on surveillance. World Health Organization.

Yarbrough VL, Winkle S, Herbst-Kralovetz MM (2014) Antimicrobial peptides in the female reproductive tract: a critical component of the mucosal immune barrier with physiological and clinical implications. Human reproduction update $21: 353-377$

Yenugu S, Hamil KG, Radhakrishnan Y, French FS, Hall SH (2004) The androgen-regulated epididymal sperm-binding protein, human $\beta$-defensin 118 (DEFB118) (formerly ESC42), is an antimicrobial $\beta$-defensin. Endocrinology 145: 3165-3173.

Zanich A, Pascall JC, Jones R (2003) Secreted epididymal glycoprotein 2D6 that binds to the sperm's plasma membrane is a member of the $\beta$-defensin superfamily of pore-forming glycopeptides. Biology of Reproduction 69 : 18311842.

Zasloff M (1987) Magainins, a class of antimicrobial peptides from Xenopus skin: isolation, characterization of two active forms, and partial cDNA sequence of a precursor. Proceedings of the National Academy of Sciences 84 : 54495453.

Zasloff M (2016) Antimicrobial Peptides: Do They Have a Future as Therapeutics? In: Antimicrobial Peptides Springer International Publishing, $147-154$

Zhang G, Ross C, Blecha F (2000) Porcine antimicrobial peptides: new prospects for ancient molecules of host defense. Veterinary Research $31: 277$ 296

Zhou CX, Yong-Lian Z, Xiao L, Zheng M, Leung KM, Chan MY, Lo PS, Tsang LL, Wong HY, Ho LS, Chung YW (2004) An epididymis-specific [beta]-defensin is important for the initiation of sperm maturation. Nature Cell Biology $6: 458$ 